\title{
Effects of crude oil on survival, morphology, and anatomy of two aquatic macrophytes from the Amazon floodplains
}

\author{
Aline Lopes - Sonia Maciel da Rosa-Osman • \\ Maria Teresa Fernandez Piedade
}

Received: 4 March 2009/Revised: 23 September 2009/Accepted: 28 September 2009/Published online: 19 October 2009

(C) Springer Science+Business Media B.V. 2009

\begin{abstract}
Aquatic herbaceous macrophytes grow in profusion in the Amazon fertile varzea floodplains. A large number of species occur but only a few are particularly abundant, supporting food chains, contributing substantially to carbon and nutrient cycles. Their growth and role in the ecosystem depend, among other, on its life cycles and habits, floating or semi-aquatic. Although in the last decades, petroliferous activity intensified in the Central Amazon region and so did oil spills, the effect of petroleum on the native aquatic plants is unknown. The present study was designed to test experimentally the survival and morpho-anatomical modifications of the free floating water hyacinth Eichhornia crassipes and the semi-aquatic grass Echinochloa polystachya to 10 different concentrations of crude oil. Higher concentrations of crude oil caused the mortality in both species; however, lethal dose $\left(\mathrm{LD}_{50}\right)$ values showed that E. polystachya was more sensitive than
\end{abstract}

Handling editor: S. M. Thomaz

A. Lopes $(\bowtie)$ - S. M. da Rosa-Osman · M. T. F. Piedade Instituto Nacional de Pesquisas da Amazônia, Projeto INPA/Max-Planck, Grupo MAUA, Av. André Araujo 2936, Aleixo, 69060-001 Manaus, Amazonas, Brazil e-mail: alopesmga@gmail.com

S. M. da Rosa-Osman e-mail: smrosa@inpa.gov.br

M. T. F. Piedade

e-mail: maitepp@inpa.gov.br
E. crassipes. Despite the higher tolerance of E. crassipes, the inhibition of root and leaf growth as well as anatomical modifications in leaves were registered in higher concentrations. Additionally, the oil caused a reduction in leaf numbers in both species. Although mortality of the floating species was lower, it may increases over time, since important alterations in morphology and anatomy occurred. These results show that oil spills in the Amazon varzea can cause severe alterations in the aquatic flora and in the floodplain dynamics.

Keywords Herbaceous plants $\cdot$ Echinochloa polystachya $\cdot$ Eichhornia crassipes $\cdot$ Central Amazon $\cdot$ Bioindicators

\section{Introduction}

Petroliferous regions are under the constant risk of accidents, as much during the process of extraction, as during the transport of crude oil (Val \& Almeida-Val, 1999; Keramitsoglou et al., 2003). In the Amazon, the oil extracted in Urucu (Coari, Amazonas State-AM, Brazil) is transported by rafts along the Solimões River, to the refinery in Manaus, AM. An oil spill accident during such transportation could seriously affect the floodplain (Val \& Almeida-Val, 1999), particularly the low varzea areas (Wittmann et al., 2002) where a greater density of aquatic grasses occurs (Junk \& Piedade, 1993). 
Amazonian aquatic grasses are very important for the aquatic ecosystem because of their huge biomass accumulation. Some species, such as Echinochloa polystachya (H.B.K.) Hitchcock, Poaceae, can produce $108 \mathrm{t} \mathrm{ha}^{-1}$ year ${ }^{-1}$ of dry matter (Piedade et al., 1991). Moreover, its submerged phytomass forms a complex environment, composed of stems and roots that are colonized by invertebrates and algae (Junk, 1973), in which many species of fish are reliant (Junk \& Howard-Williams, 1984; Sanchez-Botero \& Araujo-Lima, 2001, Claro-Jr. et al., 2004). Although petroleum extraction has taken place in the central Amazon region for more than a decade, studies concerning crude oil toxicity in these plants are rare (Lopes, 2007).

The impact of crude oil on the environment depends on the specific characteristics of both the crude oil and the environment. Light oils are easily absorbed and, since they act at the cellular level, are immediately toxic to the plants. Heavy oils cover the plants causing asphyxia and hindering gaseous exchange (Pezeshki et al., 2000). When oil spills occur in a terrestrial environment, it directly affects the ecosystem through soil contamination; however, in aquatic environments, the floating oil on the water surface is dispersed through the action of wind and waves in the littoral region, thus affecting the terrestrial environment and vegetation (Pezeshki et al., 2000). In the case of the Amazon region, this dispersion might be maximized by the oscillation of the water level, due to the flooding pulse (Junk et al., 1989).

The entrance of petroleum into the aquatic-terrestrial system results in a series of alterations, such as the substantial increase of organic material as a result of the death and decomposition of plants (Akinluyi \& Odeyemi, 1987), alterations in $\mathrm{pH}$ of the soil and the introduction of heavy metals, such as nickel and mercury (Ekundayo \& Obuekwe, 2000). These alterations, coupled with the differentiated sensitivity of each species of plant, result in modifications in the composition of the community of aquatic plants (Burk, 1977; Pezeshki et al., 2000).

The difference in sensitivity among aquatic plants allows the use of several species to detect contamination (Swanson et al., 1991; Lewis \& Wang, 1997; Mohan \& Hosetti, 1999). The free-floating Eichhornia crassipes (Mart.) Solms. (water hyacinth), Pontederiaceae, and the emergent Echinochloa polystachya are two of the most important herbaceous species colonizing the white-water varzea floodplains in the Amazon. Due to its high tolerance to many pollutants, E. crassipes is one of the most studied floating aquatic plants, being a promising species for decontamination of polluted areas since the species has high capacity to absorb and tolerate elevated levels of heavy metal ions (Harley, 1990). On the other hand, rooted plants like E. polystachya are often more sensitive to contaminants than the floating macrophytes, and commonly used as biomonitors (Lovett-Doust et al., 1994; Lewis, 1995; Roshon et al., 1999). Therefore, evaluating the oil toxicity of these plant species with different habits may be a good way to estimate the oil impact on the ecosystem (Lewis, 1995).

Considering the potential risk of accidents due to petroliferous activity and the importance of these two plants for the ecosystem this study aims to: (1) determine the median lethal concentrations for species E. crassipes and E. polystachya exposed to the Urucu crude oil; (2) evaluate changes in leaf production, and leaf and root length for both species; and (3) perform an anatomical analysis of leaves of E. crassipes with visible modifications.

\section{Materials and methods}

The aquatic macrophytes were collected on Marchantaria island (03.15S, 060.00W), in the Central Amazon, Amazonas, Brazil in May of 2006. The two species used have been chosen due to their wide distribution throughout the floodplain, for being native to the Amazon and typical of the varzea ecosystem. The soil for the experiment with E. polystachya was sampled in the same location. The experiment was performed in the greenhouse of the project INPA/ Max-Planck, Manaus, Amazonas, Brazil.

Crude oil from the Petroliferous Base of Urucu (Amazonas, Brazil) was used in the experiment. This oil is considered light, with 45.8 API degrees (ANP, 2008). See Table 1 for oil composition (Petrobrás, 1997).

\section{Experimental design}

A total of 130 young E. crassipes plants, with three leaves of $\sim 4 \times 7 \mathrm{~cm}$, were washed in tap water in the laboratory, for the removal of sediment and placed in vases with 21 of water where they remained for 30 days for growth and acclimatization. 
Table 1 Composition of Urucu crude oil (Petrobrás, 1997)

\begin{tabular}{lr}
\hline Motor octane number (distillation cut point $\left.16-180^{\circ} \mathrm{C}\right)$ & 38.0 \\
Hydrocarbon types (\% of total; distillation cut point & \\
$\left.16-180^{\circ} \mathrm{C}\right)$ & 64.8 \\
Paraffins & 20.2 \\
Naphthalenes & 15.0 \\
Aromatics & \\
Hydrocarbon types $(\%$ of total; distillation cut point & \\
144-244 $\left.{ }^{\circ} \mathrm{C}\right)$ & 85.7 \\
Saturates & 13.2 \\
Aromatics & 1.1 \\
Oleffins & \\
\hline
\end{tabular}

Whenever necessary, the water level was adjusted. Parts of the culm of mature plants of E. polystachya were collected, and from each one, a $15-\mathrm{cm}$ part containing one node was taken. The propagules were planted in vases with 21 of varzea soil (70.5\% clay, $17.92 \%$ silt, $8.97 \%$ coarse sand, $2.61 \%$ fine sand) (A. Lopes, unpublished data). After 30 days, 130 young plants with at least $30 \mathrm{~cm}$ of height were selected to perform the experiment. The plants were irrigated daily throughout the experimental period using water from an artesian well. Sample units consisted of the 260 plastic vases $(20 \mathrm{~cm}$ of diameter by $18.5 \mathrm{~cm}$ of height) distributed in factorial experiments in a completely randomized design $2 \times 10$ (species $\times$ oil dosage) with 13 replicates per treatment.

After the period of acclimatization and growth, crude oil was placed on the surface of the soil and water without mixing with the substratum and avoiding direct contact with leaves. Plants were randomly distributed in 10 treatments $(0,0.08,0.16,0.32,0.66$, $1.32,2.64,5.29,10.59$, and $15.891 \mathrm{~m}^{-2}$ ). Leaves with more than $30 \%$ of green area were counted weekly, and their length and width were measured over 35 days (E. polystachya) and 90 days (E. crassipes). The root length was measured in the beginning and at the end of the experiment for E. crassipes. This measurement was not possible in E. polystachya which was fixed in the ground. In order to calculate the value of the lethal dose $\left(\mathrm{LD}_{50}\right)$, the plants remained in the treatments for 132 days with the same oil dosages to compare the time of survival of both species. For assessment of the $\mathrm{LD}_{50}$, the OECD toxicity protocol 227 was used (OECD, 2006).

The anatomical analyses of E. crassipes leaves were carried out after 90 days of exposure to crude oil, by sampling leaves presenting visible alterations and leaves in the control group and storing them in $70 \%$ ethanol. Transversal sections were performed in the bulb and the median region of leaves for the mounting of semi-permanent microscope slides. The histological sections were cleared with sodium hypochlorite, washed with distilled water, stained with Safra-blau coloration, placed over microscope slides and cover slips with a drop of glycerin, and embedded with nail polish. Observations of the histological sections were performed using an optic microscope Leica ${ }^{\mathrm{TM}}$, in $5 \times$ to $40 \times$ objectives. Photomicrographs were taken using an optic microscope Zeiss ${ }^{\mathrm{TM}}$ MC 63 in objectives $2.5 \times, 20 \times$, and $40 \times$.

Statistical analysis

Statistical analyses were performed using the following software: Systat 10.2 (Systat, 2002); Microsoft Office Excel 11.0 (Microsoft Corporation, 2003); and Trimmed Sperman-Karber Method (Hamilton et al., 1977). In order to evaluate the effect of the time and the dosage of crude oil on leaf length and the increase in leaf number, we used two-way ANOVA for repeated measures taking into account assumptions of homocedasticity and spherecity. Data from day 0 to the 35 th day of plant exposure to crude oil were used to analyze the effect of crude oil on leaf length. This was done to minimize the amount of sample reduction due to mortality in treatments of a higher concentration. Furthermore, for E. polystachya the data for concentrations up to $0.321 \mathrm{~m}^{-2}$ were used, due to the high mortality of the plants from the beginning of the experiment. The difference between the root length of E. crassipes in the beginning and at the end of experiment was compared by two-way ANOVA. In order to confirm the result, a paired $t$ test for each group of treatment was used. An estimation of $\mathrm{LD}_{50}$ values with a dosage able to kill $50 \%$ of the tested population was obtained through the statistic method of Spearman-Karber, with $95 \%$ of confidence interval (Hamilton et al., 1977; OECD, 2006).

\section{Results}

Seventy days after the application of crude oil, the death of all the plants of E. crassipes exposed to the concentrations of 10.59 and $15.891 \mathrm{~m}^{-2}$ was 
observed. E. polystachya was even more sensitive to crude oil as 4 days after the exposure all plants exposed to the $5.29,10.59$, and $15.89 \mathrm{l} \mathrm{m}^{-2}$ died and after 35 days all plants exposed to dosages above $0.661 \mathrm{~m}^{-2}$ also died. In E. crassipes, many modifications in the plants exposed to crude oil were observed. These modifications include the reduction of total plant size, shortening of bulbs, and reduction of size and thickness of leaves.

At 91 days of exposure, the $\mathrm{LD}_{50}$ for E. crassipes was calculated as $1.241 \mathrm{~m}^{-2}$ (Fig. 1a). For E. polystachya, after 4 days the $\mathrm{LD}_{50}$ was $0.471 \mathrm{~m}^{-2}$ (Fig. 1b). After 49 days, the E. polystachya had reached $100 \%$ of mortality in all treatments, except the control, which did not show growth inhibition.

The ANOVA with repeated measures showed that leaf increase of E. crassipes (Fig. 2a) throughout 35 days was affected by crude oil dosage $(F(9,120)=$ 9.16, $P<0.0001)$, by exposure time $(F(5,600)=$ 18.72, $P<0.0001)$, and by the interaction between dosage and exposure time $(F(45,600)=6.51$, $P<0.0001)$. During the same period of time, however, with only a 0.32-1 dosage, E. polystachya (Fig. 2b) was affected by dosage $(F(3,21)=4.013$,
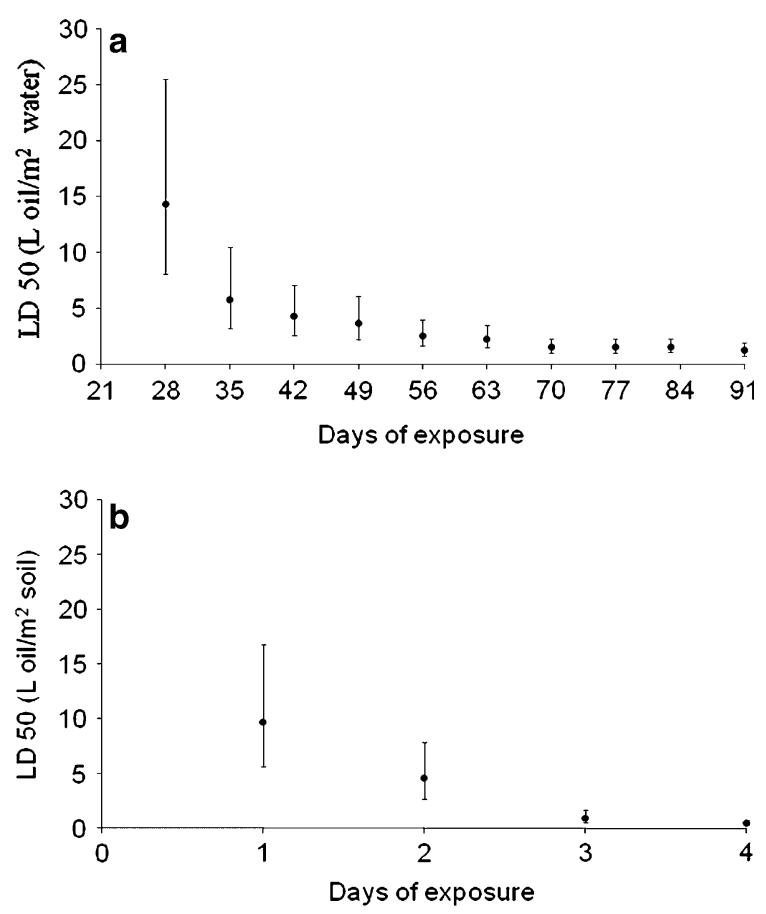

Fig. 1 Toxicity of Urucu's crude oil expressed in $\mathrm{DL}_{50}$ values, for: a $E$. crassipes; $\mathbf{b}$ E. polystachya throughout exposure time. Values with $95 \%$ confidence intervals
$P=0.021)$ and exposure time $(F(5,150)=2.972$, $P=0.015)$, the interaction between these factors was not significant $(F(45,150)=1.583, P=0.091)$.

Length and width of $E$. crassipes leaves showed a strong correlation $(r=0.89)$, therefore only the results for length are presented. There was a reduction of leaves in E. crassipes due to the dosage of crude oil $(F(9,119)=2.84, P=0.005)$ and to exposure time $(F(5,595)=48.22, P<0.0001)$, there was a significant interaction between these factors $(F(45,595)=$ 4.10, $P<0.0001)$. In Fig. 3a, the stabilization pattern of leaves in treatments ranging from 0 to 0.081 is very similar, while there is a pronounced growth reduction in concentrations greater than $1.321 \mathrm{~m}^{-2}$. There was no significant effect of crude oil dosage on the leaf length of $E$. polystachya $(F(3,21)=1.48, P=$ $0.249)$, although exposure time presented a significant effect $(F(5,105)=26.469, P<0.0001)$. As Fig. $3 b$ shows, there was no significant interaction between crude oil dosage and exposure time $(F(45,105)=$ $1.391, P=0.165)$.

The difference in the E. crassipes root length between the beginning and the end of the experiment was influenced by the dosage of oil $(F(9,120)=2.27$, $P=0.02)$. Individual differences were found between the treatments 0.08 and $5.291 \mathrm{~m}^{-2}(P<0.05)$. The paired $t$ test confirmed that the oil dosage caused root growth inhibition, except in the $0.661 \mathrm{~m}^{-2}$ dose, where there was stimulation of growth, compared to the control group (Fig. 4). In the other dosages, there was no significant difference between initial and final root length, varying from 8 to $12 \mathrm{~cm}$ at the end of the experiment.

It was not possible to carry out anatomy analysis of E. polyastachya leaves due to high mortality in all treatments. Anatomic analysis of E. crassipes leaves showed an increase in the size of aerenchyma air spaces in treatments 5.29 and $10.59 \mathrm{l} \mathrm{m}^{-2}$ and in higher dosages this tissue disappeared (Fig. 5a-d). There was also a displacement of aerenchyma air spaces in treatments 5.29 and $10.591 \mathrm{~m}^{-2}$ (Fig. 5b, c), which were organized in the central region of the leaf in the control group (Fig. 5a). Palisade parenchyma was gradually diminished with crude oil dosage, until it could no longer be visualized in treatment $15.891 \mathrm{~m}^{-2}$ (Fig. 5d). In the control group (Fig. 5a), a vascular cylinder was observed in the central line of the leaf area but this suffered a drastic disorganization due to exposure to the oil (Fig. 5b-d). The main 
Fig. 2 Dosage effect of crude oil and exposure time (days) on the leaf number of: a Eichhornia crassipes; b Echinochloa polystachya. Mean values with standard error $(n=13)$
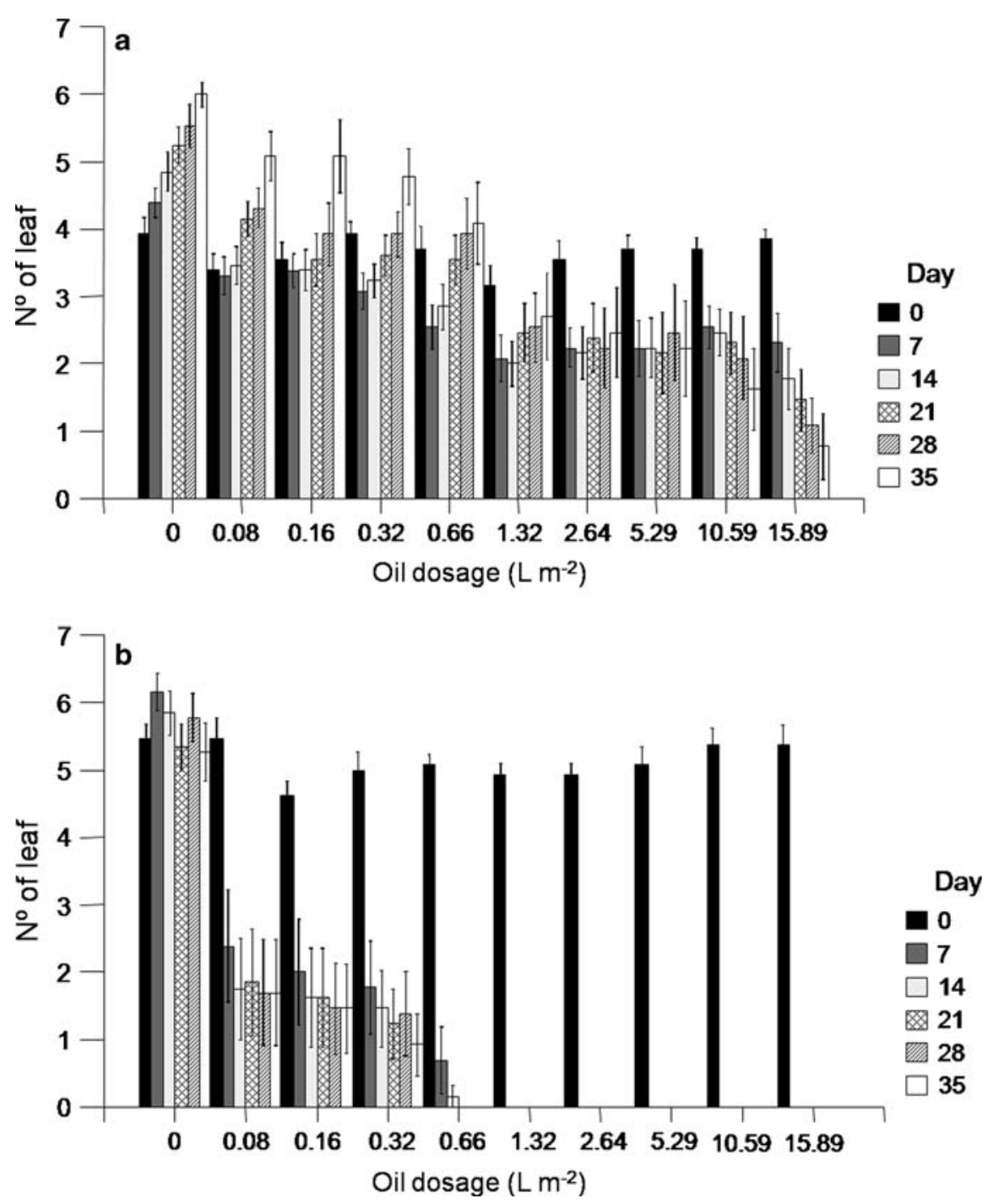

change observed in the bulb of E. crassipes, beyond the morphologic alterations such as the drastic reduction of the size and thickness of the bulb, was the reduction of the cellular size with the increase of oil dosage (Fig. 6a-d). Moreover, there was the disappearance of aerenchyma tissue in the treatments with higher dosages of crude oil (Fig. 6b-d).

\section{Discussion}

The effect of petroleum hydrocarbons on the mortality of plants has been reported by several authors as an efficient measure of crude oil impact on the affected ecosystem (Mendelssohn \& McKee, 1988; Pezeshki et al., 2001; Lin et al., 2002). Besides the hydrocarbons that are toxic to plants, Urucu crude oil has $5 \mathrm{ppm}$ of nickel, $5 \mathrm{ppm}$ of vanadium, and $0.05 \%$ (wt) of sulfur (Petrobrás, 1997; ANP, 2008). The toxicity of heavy-metal ions is due chiefly to their interference with electron transport in respiration and photosynthesis, and the inactivation of vital enzymes. As a result, the energy status is lowered and the uptake of mineral nutrients decreases, reducing growth (Larcher, 1995). The magnitude of such an impact for the environment can be evaluated by means of alterations in the growth and development of the plants. 
Fig. 3 Effect of crude oil concentration and exposure time (days) on leaf length of: a Eichhornia crassipes; b Echinochloa polystachya. Means values with standard error $(n=13)$. For

E. polystachya, statistical analysis was performed at a concentration of $0.661 \mathrm{~m}^{-2}$
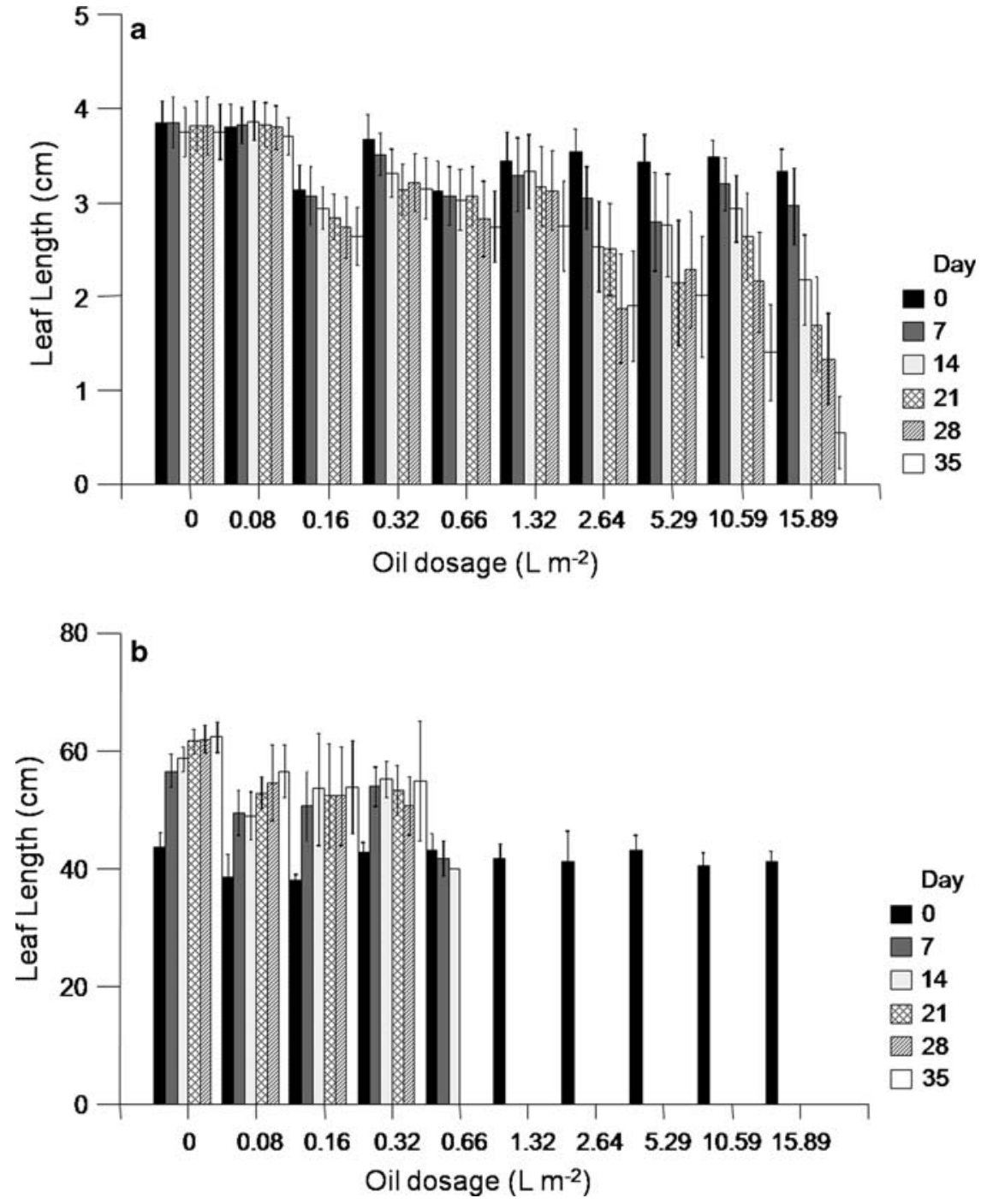

Due to the high mortality of E. polystachya, it was not possible to verify the effect of crude oil on the growth of this species. This suggested that concentrations above $0.321 \mathrm{~m}^{-2}$ may be limiting for this species. For E. crassipes, crude oil caused a reduction of leaf size and even though some individuals survived for a longer time, they presented morphoanatomical modifications, irregular distribution of the aerenchyma air spaces or even its absence. The reduction of thickness of aerenchyma air spaces occurred in the bulb of plants exposed to dosages above $0.661 \mathrm{~m}^{-2}$. Aerenchyma is an adaptation in aquatic plants which gives buoyancy and allows the photosynthetic parts to be maintained above the water column (Junk \& Piedade, 1997). The loss of this adaptation in the leaves and in the bulb may cause the plant to sink increasing its contamination and resulting in its death.

Light oils such as the one found in Urucu act on the cellular level changing membrane permeability or interrupting several metabolism processes of the plant. Thus, their toxicity for the plants is immediate. On the other hand, the effect of heavy oils is gradual by causing physical damage, which results in asphyxia and the interruption of gas exchange (Pezeshki \& DeLaune, 1993). In this study, morpho-anatomical modifications which suggest a drastic modification of plant metabolism were found. The reduction of leaf size and the loss of palisade parenchyma in E. crassipes are important factors in 


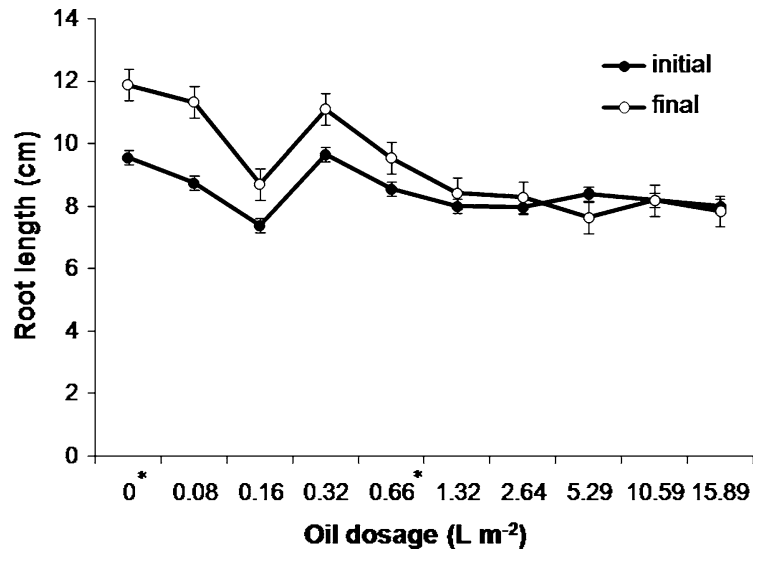

Fig. 4 Effect of crude oil concentration on E. crassipes root length. Mean values with standard error $(n=13)$. * Indicates the treatments where there is a significant difference between the initial and final root length value $(\alpha=0.05)$

the subsequent death of the plants. This indicates the high degree of stress caused by this pollutant.

The reduction of thickness and even the loss of palisade parenchyma tissue resulting from exposure to the oil indicate that, even if the plant produces new leaves they will have their functions compromised. Palisade parenchyma is located generally in the adaxial or upper surface of the leaves and consists of areas of elongated cells, rich in chloroplasts, placed perpendicularly to the surface of the foliar limb, presenting intercellular spaces (Souza, 2003).
This is the main tissue responsible for the photosynthesis of tracheophytes and presents high plasticity in response to environmental factors for a wide diversity of plants (Justo et al., 2005), including E. crassipes, as demonstrated in this study.

Based on experiments with industrial effluents, Ferreira \& Graça (2002) concluded that radicle development is a good endpoint for toxicity tests with aquatic macrophytes. The inhibition of root elongation of E. crassipes occurred in doses of petroleum that may be considered too low, from 0.08 to $15.89 \mathrm{l} \mathrm{m}^{-2}$ of water. This confirms root elongation as a robust parameter that may be used to asses the damage caused by oil in this species. According to the study of Lin et al. (2002), an inhibitory effect on the length of roots of Spartina alterniflora Loisel. was found when using the oil No. 2 in dosages from 5 to $201 \mathrm{~m}^{-2}$. Studies on herbaceous plants suggest that root growth and physiological activity are dependent upon a continuous supply of assimilate (Richards, 1989). The inhibition of root growth causes a reduction in nutrient absorption, increasing the plant's stress and hampering their development. Disturbance in the absorption of nutrients leads to adjustments in distribution of assimilates, in the ratio of shoot to root growth, inducing, eventually, premature flowering and leaf abscission (Larcher, 1995). Although in the present study the roots of E. polystachya were not measured, Lopes \& Piedade (2009) did not find changes in the
Fig. 5 Transverse sections of Eichhornia crassipes leaves after 90 days of exposure to Urucu crude oil, at concentrations of: $\mathbf{a} 0$; $\mathbf{b}$ 2.64; c 5.29; d $15.891 \mathrm{~m}^{-2}$ of water. ie Inferior epidermis, se superior epidermis; $p p$ palisade parenchyma; $s p$ spongy parenchyma; ae aerenchyma air space; $e$ estomate; $v c$ vascular cylinder. Magnification of $\times 400$ for control and $\times 200$ for other treatment groups
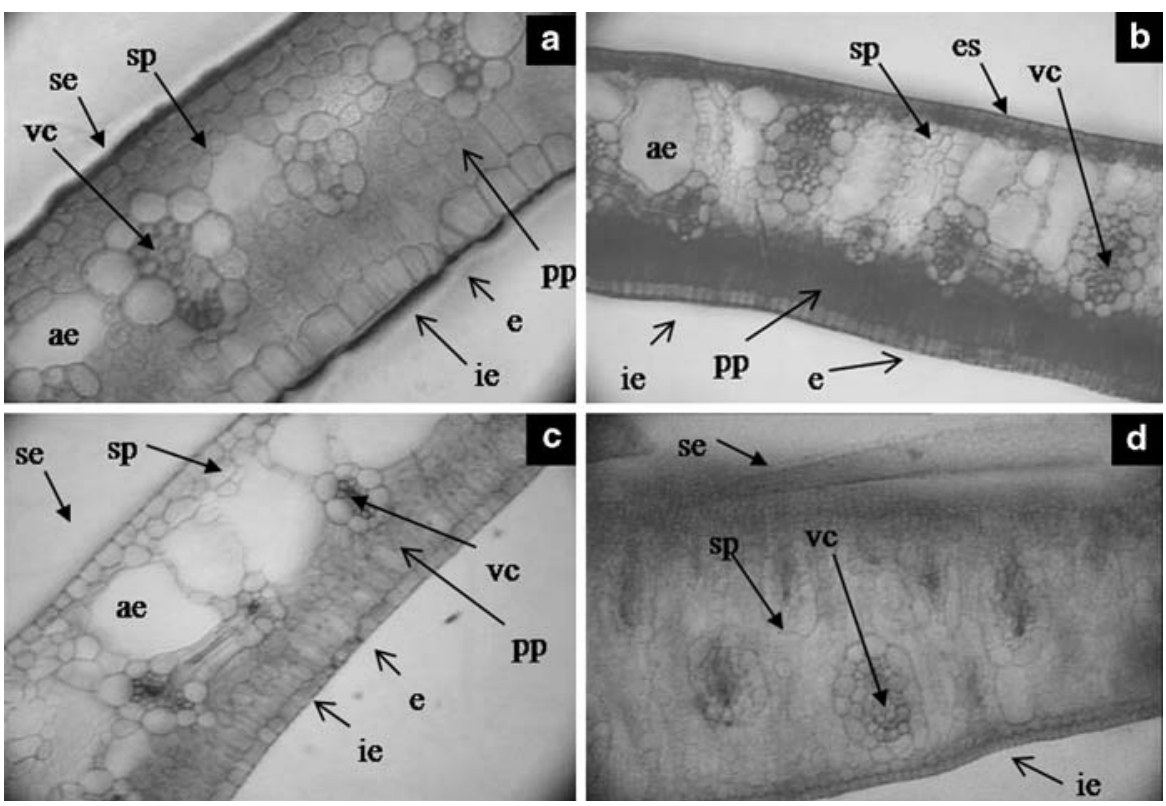
Fig. 6 Transverse sections of Eichhornia crassipes bulb after 90 days of exposure to Urucu crude oil, in dosages of: a 0 ; b 2.64; c 5.29 ; d $15.891 \mathrm{~m}^{-2}$ of water. $s p$ Spongy parenchyma; ae aerenchyma air space. Magnification is $\times 25$
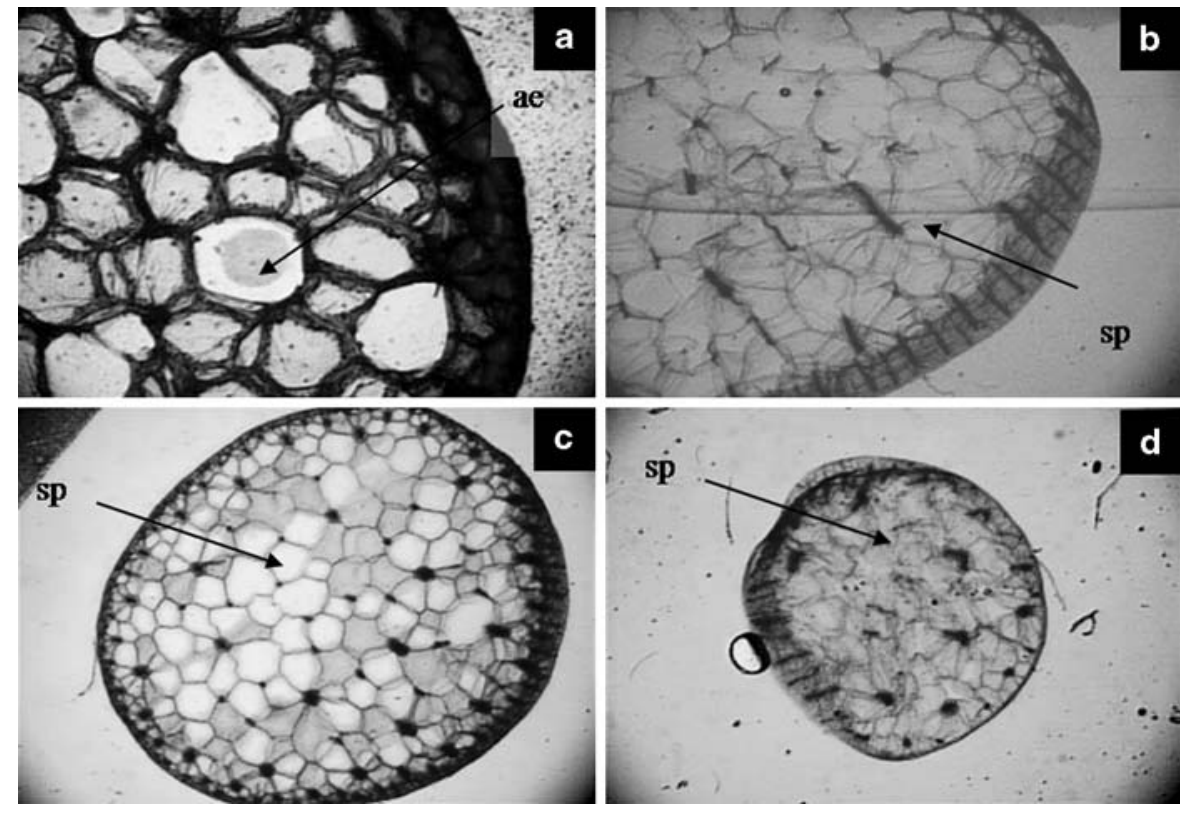

root biomass of $E$. polystachya after 70 days growing in soil contaminated with Urucu crude oil. This shows that this parameter is not a good endpoint for this species when exposed to petroleum products.

These results indicate that Urucu's crude oil cause more severe effects on E. polystachya than on E. crassipes. While after 91 days of exposure, the median lethal dose estimated for E. crassipes was $1.24 \mathrm{l} \mathrm{m}^{-2}$, in E. polystachya only 4 days of exposure were necessary to reach a similar mortality level in $0.471 \mathrm{~m}^{-2}$. Besides differences in the sensitivity of both species, the substratum they occupy may be of importance. In the aquatic system, only the soluble part of the oil will reach the water column interacting with the roots, while a fluctuating layer that does not dissolve in the water column is formed (Val \& Almeida-Val, 1999). On the other hand, the insoluble part of the oil penetrates in the soil, eventually reaching the root system where the pollutant becomes available for absorption by the plants. The implication of such differences in the case of an oil spill in varzea ecosystems is that crude oil could cause immediate damage to E. polystachya, while to E. crassipes damage would be evident only after a prolonged exposure.

Experiments performed with the oral ingestion of Urucu's crude oil by Hoplosternum littorale (tamoatá), a facultative air breathing fish showed that only one ingestion of $3 \mathrm{ml} \mathrm{kg}^{-1}$ of crude oil caused physiological alterations; however, no death was observed during the exposure time $(72 \mathrm{~h}$ ) (Brauner et al., 1999). In the present study, during the same period of time, the death of $80 \%$ E. polystachya individuals submitted to dosages from 0.08 to $15.891 \mathrm{~m}^{-2}$ of crude oil occurred. Thus, even though crude oil may not be immediately lethal to fish, it would cause the loss of habitat and the accumulation of dead organic matter in the environment. The decomposition of this material will further decrease oxygen availability in varzea ecosystems. Heavy metals would also contaminate the dead organic matter (Osuji \& Adesiya, 2005) and when decomposition takes place toxic elements may be incorporated into the trophic chains via the ingestion of plant material by invertebrates, preferential food items of several fish species.

Recently, concerns have arisen on the possibility of oil spills in the varzea, especially during the critical phase of recruitment for some key plant species of this ecosystem. Thus, what would be the implications of a high mortality of E. crassipes and E. polystachya in the case of a Urucu's oil spill accident? Emergent and floating plants are important to fish, wildlife, and humans. Several articles have summarized the value of these plants for fish and wildlife (Killgore et al., 1993; Mol et al., 2007; Pelicice et al., 2008). Together with fish like Arapaima gigas (pirarucu), an exclusive air breather, several Amazon fish feed on terrestrial invertebrates which inhabit aquatic macrophytes 
during the period of high waters, such as the Parauchenipterus galeatus (cangati), the Mylossoma duriventre (pacú-manteiga), and Triportheus elongatus (sardinha) (Claro-Jr. et al., 2004). The contamination of leaves of aquatic macrophytes with crude oil would cause the contamination of fish with crude oil. Other animals, such as the manatee (Trichechus inunguis), use E. polystachya (13.8\%) and E. crassipes (11.2\%) among their most important feeding items (Colares \& Colares, 2002) and therefore, the death of these plants could cause a drastic reduction in the feeding options for this mammal. Due to their dense mass of roots, E. crassipes provide habitat for fish, fingerlings, insects, and other aquatic organisms (Junk \& Howard-Williams, 1984). Humans also benefit from these plants because groups of emergent plants and free-floating plants dampen the force of waves which reduces shoreline erosion (Piedade \& Junk, 2000). Furthermore, one of the most concerning effects of these plants' death would be the incorporation of a large quantity of dead biomass to the system, coupled with the amount of carbon that would no longer be fixed, estimated by Piedade et al. (1991) as 3.99 $\mathrm{kg} \mathrm{m}^{-2}$ of carbon. Thus, an oil spill in the varzea ecosystem causing damage to the flora would lead to direct and indirect damages to the fauna in these environments, especially the fish fauna, due to increased organic load and surface modification at the air/water interface, oxygen, and habitat reduction.

\section{Conclusion}

Concentration and exposure time are two important factors in the determination of the effect of crude oil on E. polystachya and E. crassipes. The determination of median $\mathrm{LD}_{50}$ showed to be an effective method in evaluating the influence of these factors on the vegetation of ecosystems exposed to the risk of contamination by this pollutant.

When exposed to low dosage, E. crassipes survived for a long period of time, however, exposure to E. polystachya, for only a few days led to high mortality. Although E. crassipes survived a long period of time in a contaminated environment, plants were extremely affected by crude oil; this could be observed by the morpho-anatomical modifications in the leaves.
Higher concentrations of crude oil from Urucu caused a high mortality to E. crassipes and E. polystachya, whereas at low concentrations an inhibition of the growth of these species occurred. Further studies should be conducted to clarify the modifications in the metabolism of the plants responsible by growth inhibition. For instance, measures of photosynthetic rates and the quantification of nutrients and heavy metals in the living biomass and substratum could be studied.

The Amazon region depends on river transport for a large part of its trade, including oil transportation. On the other hand, the varzea ecosystems are very important areas for the regional economy owing to activities in fisheries, agro-forestry, and tourism. Oil spills in the Amazon/Solimões River could certainly have a negative impact on the varzea biota and ecosystem for they may compromise the population of key plant species of these floodplains. Therefore, long-term investigations on the effects and control of spills are crucial in helping the conservation, biodiversity, and sustainable management of these environments.

Acknowledgments This work is part of the GEOMA-Áreas Alagáveis Network Project, Brazilian Ministry of Science and Technology, MCT. Funding supporting this research was provided by INPA/Max-Planck Project, PPI 1090-5. Petrobras Oil Company provided oil through the PIATAM project. With thanks to Conselho Nacional de Pesquisas (CNPq) for Aline Lopes and Sonia Maciel Rosa-Osman masters Grants; CT-Petro Network (MCT/CNPq) for Aline Lopes Grant; INPA/MaxPlanck Project, Laboratório de Ecofisiologia e Evolução (LEEM) and Laboratório Temático de Microscopia Óptica e Eletrônica for logistical and technical support.

\section{References}

Akinluyi, T. O. \& O. Odeyemi, 1987. Decreasing fish productivity in the Niger delta of Nigeria. A microbiological perspective. Nigerian Journal of Applied Science 5: 97-105.

ANP - Agência Nacional do Petróleo, Gás Natural e Biocombustíveis, 2008. Despacho do Diretor-Geral no. 683, Anexo II: relação de tipos de petróleo nacional: 13 pp [cited 18 Feb 2009; available on Internet at http:// www.anp.gov.br/doc/participacoes_governamentais/2008/ Revisao_2008.pdf].

Brauner, C. J., M. M. Ballantyne \& A. L. Val, 1999. Crude oil exposure affects air-breathing frequency, blood phosphate level and ion regulation in an air-breathing teleost fish, Hoplosternum littorale. Comparative Biochemistry and Physiology. Part C 123: 127-134. 
Burk, C. J., 1977. A four year analysis of vegetation following an oil spill in a freshwater marsh. The Journal of Applied Ecology 14: 515-522.

Claro-Jr., L., E. Ferreira, J. Zuanon \& C. Araújo-Lima, 2004. $\mathrm{O}$ efeito da floresta alagada na alimentação de três espécies de peixes onívoros em lagos de várzea da Amazônia Central, Brasil. Acta Amazônica 34(1): 133-137.

Colares, I. G. \& E. P. Colares, 2002. Food plants eaten by Amazonian Manatees (Trichechus inunguis, Mammalia: Sirenia). Brazilian Archives of Biology and Technology 45(1): 67-72.

Ekundayo, E. O. \& O. Obuekwe, 2000. Effects of an oil spill on soil physico-chemical properties of a spill site in a typic udipsamment of the Niger delta basin of Nigeria. Environmental Monitoring and Assessment 60: 235-249.

Ferreira, R. C. F. \& M. A. S. Graça, 2002. A comparative study of the sensitivity of selected aquatic plants to mining effluents. Limnetica 21(1-2): 129-134.

Hamilton, M. A., R. C. Russo \& R. V. Thurst, 1977. Tirmmed Spearman-Kraber method for estimating median lethal concentrations in toxicity bioassays. Environmental Science Technology 11(7): 714-719.

Harley, K. L. S., 1990. The role of biological control in the management of water hyacinth, Eichhornia crassipes. Biocontrol News and Information 11: 11-22.

Junk, W. J., 1973. Investigations on the ecology and production biology of the "floating meadows" (Paspalo-Echinocloetum) on the middle Amazon. Part II. The aquatic fauna in the root zone of floating vegetation. Amazoniana 4(1): 9-12.

Junk, W. J. \& C. Howard-Williams, 1984. Ecology of aquatic macrophytes in Amazonia. In Sioli, H. (ed.), The Amazon Limnology and Landscape Ecology of a Mighty Tropical River and its Basin. W. Junk, Dordrecht: 269-293.

Junk, W. J. \& M. T. Piedade, 1993. Biomass and primaryproduction of herbaceous plant communities in the Amazon floodplain. Hydrobiology 263: 155-162.

Junk, W. J. \& M. T. Piedade, 1997. Plant life in the floodplain with special reference to herbaceous plants. In Junk, W. J. (ed.), The Central Amazon Floodplain, Vol. 126. Springer, New York:147-181.

Junk, W. J., P. B. Bayley \& R. E. Sparks, 1989. The flood pulse concept in river-floodplain systems, In Dodge, D. P. (ed.), Proceedings of the International Large River Symposium. Canadian Special Publication of Fisheries Aquatic Sciences, Ottawa: 110-127.

Justo, C. F., Â. M. Soares, M. L. Gavilanes \& E. M. de Castro, 2005. Leaf anatomical plasticity of Xylopia brasiliensis Sprengel (Annonaceae). Acta Botanica Brasilica 19(1): 112-123.

Keramitsoglou, I., C. Certalis \& P. Kassomenos, 2003. Decision support system for managing oil spill events. Environmental Management 32(2): 290-298.

Killgore, K. J., E. D. Dibble \& J. J. Hoover, 1993. Relationships Between Fish and Aquatic Plants: A Plan of Study. U.S. Army Engineer Waterways Experiment Station, Miscellaneous Paper A-93-1, Vicksburg, MS.

Larcher, W., 1995. Physiological Plant Ecology: Ecophysiology and Stress Physiology of Functional Groups, 3rd ed. Springer, Berlim, Heidelberg.
Lewis, M. A., 1995. Use of freshwater plants for phytotoxicity testing: a review. Environmental Pollution 87: 319-336.

Lewis, M. A. \& W. Wang, 1997. Water quality and aquatic plants. In Wang, W., J. W. Gorsuch \& J. S. Hughes (eds), Plants for Environmental Studies. CRC Lewis Publishers, New York: 141-175.

Lin, Q., I. A. Mendelssohn, M. T. Suidam, K. Lee \& A. D. Venosa, 2002. The dose-response relationship between No. 2 fuel oil and the growth of the salt marsh grass, Spartina alterniflora. Marine Pollution Bulletin 44: 897-902.

Lopes, A., 2007. Respostas de Herbáceas Aquáticas Amazônicas ao Petróleo Cru de Urucu (Coari - AM) [dissertation]. [Manaus (AM)]: Instituto Nacional de Pesquisas da Amazônia/Universidade Federal do Amazonas. 129 pp.

Lopes, A. \& M. T. F. Piedade, 2009. Estabelecimento de Echinochloa polystachya (H.B.K.) Hitchcock (Poaceae) em solo de várzea contaminado com petróleo de Urucu. Acta Amazônica 39(3): 571-578.

Lovett-Doust, J., M. Schmidt \& L. Lovett-Doust, 1994. Biological assessment of aquatic pollution: a review, with emphasis on plants as biomonitors. Biological Reviews 69: $147-186$

Mendelssohn, I. A. \& K. L. McKee, 1988. Spartina alterniflora dieback in Louisiana: time-course investigation of soil waterlogging effects. The Journal of Ecology 76: 509-521.

Microsoft Corporation, 2003. Microsoft Office Excel, version 11.0. Redmond, WA, USA.

Mohan, B. S. \& B. B. Hosetti, 1999. Aquatic plants for toxicity assessment. Environmental Research 81: 259-274.

Mol, J. H., B. de Mérona, P. E. Ouboter \& S. Sahdew, 2007. The fish fauna of Brokopondo Reservoir, Suriname, during 40 years of impoundment. Neotropical Ichthyology 5: 351-368.

Organization for Economic Cooperation and Development (OECD), 2006. Test No. 227: Terrestrial Plant Test: Vegetative Vigour Test. OECD guidelines for the testing of chemicals [cited 8 Feb 2009; available on internet at http://browse.oecdbookshop.org/oecd/pdfs/browseit/9722 701E.PDF].

Osuji, L. C. \& S. O. Adesiyan, 2005. Extractable hydrocarbons, nickel and vanadium contents of Ogbodo-isiokpo oil spill polluted soils in Niger Delta, Nigeria. Environmental Monitoring and Assessment 110: 129-139.

Pelicice, F. M., S. M. Thomaz \& A. Agostinho, 2008. Simple relationships to predict attributes of fish assemblages in patches of submerged macrophytes. Neotropical Ichthyology 6(4): 543-550.

Petrobrás, 1997. Características do petróleo Urucu. CNPES: SEPESQ:DIQUIM:SETAV Anexo V.

Pezeshki, S. R. \& R. D. DeLaune, 1993. Effect of crude oil on gas exchange functions of Juncus roemerianus and Spartina alterniflora. Water, Air, and Soil Pollution 68: 461-468.

Pezeshki, S. R., M. W. Hester, Q. Lin \& J. A. Nyman, 2000. The effect of oil spill and cleanup on dominant US Gulf coast marsh macrophytes: a review. Environmental Pollution 180: 129-139.

Pezeshki, S. R., R. D. DeLaune \& A. Jugsujinda, 2001. The effect of crude oil and the effectiveness of cleaner 
application following oiling on US Gulf of Mexico coastal marsh plants. Environment Pollution 112: 483-489.

Piedade, M. T. F. \& W. J. Junk, 2000. Natural grass and herbaceous plants in the Amazon floodplain and their use. In Junk, W. J. \& Ohly, J. (eds), The Central Amazon Floodplain: Actual Use and Options for a Sustainable Management. Backhuys Publishers, Leiden: 269-290.

Piedade, M. T. F., W. J. Junk \& S. P. Long, 1991. The productivity of the C4 grass Echinochloa polystachya on the Amazon floodplain. Ecology 72(4): 1456-1463.

Richards, J. H., 1989. Evaluation of root functioning of trees exposed to air pollutants. In Committee on Biologic Markers of Air-Pollution Damage in Trees (ed.), Biologic Markers of Air Pollution Stress and Damage in Forests. National Academy Press, Washington, DC: 169-183.

Roshon, R. D., J. H. McCann, D. G. Thompson \& G. R. Stephenson, 1999. Effects of seven forestry management herbicides on Myriophyllum sibiricum, as compared with other nontarget aquatic organisms. Canadian Journal of Forest Research 29: 1158-1169.
Sanchez-Botero, J. I. S. \& C. A. R. M. Araujo-Lima, 2001. As macrófitas aquáticas como berçário para a ictiofauna da várzea do rio Amazonas. Acta Amazonica 31(3): 37-448.

Souza, L. A., 2003. Morfologia e anatomia vegetal: célula, tecidos, órgãos e plântula. Editora da Universidade Estadual de Ponta Grossa, Ponta Grossa.

Swanson, S. M., C. P. Rickard, K. E. Freemark \& P. MacQuarrie, 1991. Testing for pesticide toxicity to aquatic plants: recommendations for test species. In Gorsuch, J. W., W. R. Lower, M. A. Lewis \& W. Wang (eds), Plants for Toxicity Assessment. ASTM, Philadelphia: 77-106.

Systat, 2002. SYSTAT for Windows, version 10.2. SYSTAT Software, Inc., Richmond, CA, USA.

Val, A. L. \& V. M. Almeida-Val, 1999. Effects of crude oil on respiratory aspects of some fish species of the Amazon. In Val, A. L. \& V. M. F. Almeida-Val (eds), Biology of Tropical Fishes. INPA, Manaus: 277-291.

Wittmann, F., D. Anhuf \& W. J. Junk, 2002. Tree distribution and community structure of central Amazonian várzea forests by remote-sensing techniques. Journal of Tropical Ecology 18: 820-905. 